
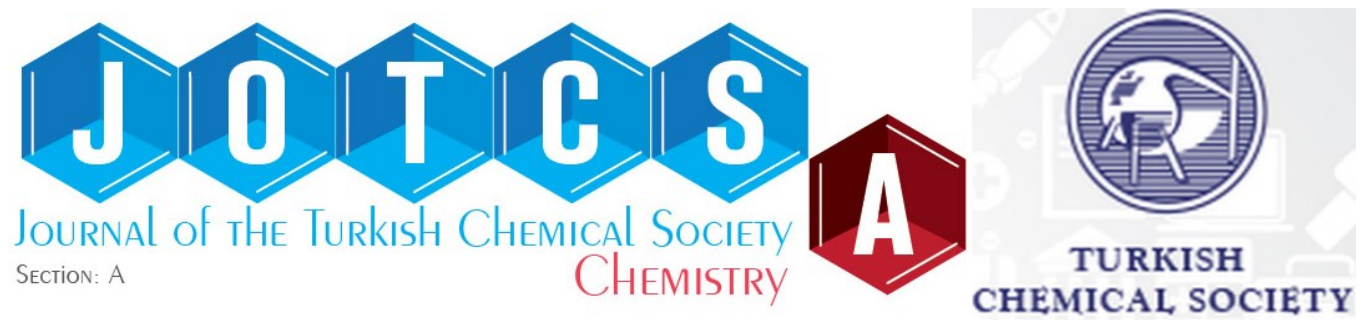

\title{
Synthesis, Characterization, and Molecular Docking Studies of Fluoro and Chlorophenylhydrazine Schiff Bases
}

\section{Ayşegül ŞENOCAK $\triangle(D$}

Tokat Gaziosmanpasa University, College of Science and Arts, Department of Chemistry, 60240, Tokat, Turkey.

\begin{abstract}
Six Schiff bases synthesized by condensation reaction of p-fluoro and chlorophenylhydrazines with some carbonyl compounds were reported in this work. Structures of the prepared compounds were elucidated by FT-IR, ${ }^{1} \mathrm{H}$ - and ${ }^{13} \mathrm{C}-\mathrm{NMR}$ spectroscopy. FT-IR spectra exhibited characteristic transitions for all compounds. Also, their structures were proved by NMR spectroscopy, especially with the imine peak which is an indicator of the formation of Schiff bases. In addition, molecular docking studies of the Schiff bases were carried out on Alzheimer's disease. The calculated docking scores and inhibition constants pointed out the probability of the usage of 2-chloro-5-nitrobenzaldehyde Schiff bases as a new drug candidate for Alzheimer's disease after structural regulations.
\end{abstract}

Keywords: Schiff base, Phenylhydrazine, NMR spectroscopy, Alzheimer's disease, Cholinesterases, Molecular docking.

Submitted: March 04, 2019. Accepted: July 08, 2019.

Cite this: Şenocak A. Synthesis, Characterization, and Molecular Docking Studies of Fluoro and Chlorophenylhydrazine Schiff Bases. JOTCSA. 2019;6(3):303-10.

DOI: https://doi.org/10.18596/jotcsa.535441.

Corresponding author. E-mail: aysegul.senocak@gop.edu.tr, ayseon@gmail.com. Tel: +90 356252 1616/3051, Fax: +90356252 1585.

\section{INTRODUCTION}

Schiff bases are regarded as one of the most studied compound group because of their potential using areas ranging from pharmacology and industry to biology and chemistry. Versatility, stability, and ease of synthesis of the Schiff bases induce their broad in scope applications containing catalysts, dyes and pigments, corrosion inhibitors, and bioactive materials (18 ). Among those applications, bioactive materials have come to the forefront especially because of the contribution of the azomethine group to bioactivity by interacting and forming hydrogen bonding with certain sites in the cell structure (9).

For the synthesis of the Schiff bases, various amine compounds have been used. Phenylhydrazine compounds are also used for this purpose especially by converting to pyrazoles and pyrazolones. In one of the studies about phenylhydrazines, Dayakar et al. synthesized a series of pyrazole and pyrazolone derivatives by refluxing phenylhydrazines with ethyl-4-chloro-3oxobutanoate (10). Besides, various pyrazole and pyrazolone compounds derived from phenylhydrazine Schiff bases were studied and reported as antimicrobial and anticancer agents by different groups (11-13). In another study, N,O-hydrazone Schiff base ligand and its complexes with nickel and copper were synthesized and catalytic effects of the complexes on oxidation of benzyl alcohol were studied (14). Finally, half-sandwich complexes of phenyl hydrazone Schiff base ligands prepared by Lapasam et al. exhibited good antibacterial activity againist $P$. aeruginosa and $B$. thuringiensis (15). 
Alzheimer's disease (AD), one of the most common neurodegenerative diseases, most commonly affects people in the 65-90 age range and many studies have been carried out on its treatment. One of the target proteins intensily used in these studies is cholinesterase enzymes. Inhibition of acetylcholinesterase (AChE) and butyrylcholinesterase (BChE) enzymes alleviates the symptoms of $A D$ regulating the level of acetylcholine in certain regions of the brain. Therefore synchronized inhibition of these two enzymes have been promising for the treatment of $A D$, which may develop for many reasons (16) and there are so many studies on inhibition of AChE and BChE in the literature (16-22).

Andrade-Jorge et al. evaluated new isoindoline and dioxoisoindoline compounds for AchE inhibition. They compared the compounds to observe the effect of carbonyl group on inhibition activity (20). A series of compounds were prepared to evaluate their AChE and BChE inhibitory activities by Arumagum et al. Molecular docking and in vitro studies showed good inhibitory activities for all compounds(21). In another study, very potent cholinesterase inhibitors based on a weak cholinesterase inhibitor called minaprine were prepared. As a result, two of the compounds exhibiting high activity were revealed for new drug active material candidates (22).

The desire to hinder waste of time and resources of scientists interesting in bioactivity studies have driven forward computer based drug design approaches over the last decades. The usage of these methods before clinic studies has been increased the efficiency drug development process. Especially enzyme inhibition studies about the diseases like tuberculosis, cancer, diabetes, Alzheimer's, and epilepsy have intensely appeared in the literature (23-26).

In this study, six Schiff bases were prepared and defined by FT-IR, ${ }^{1} \mathrm{H}$ - and ${ }^{13} \mathrm{C}-\mathrm{NMR}$ spectroscopic methods. Besides, molecular docking studies of the Schiff bases were carried out as AChE and BChE inhibitors against AD.<smiles>[X]c1ccc(NN=Cc2cc([N+](=O)[O-])ccc2Cl)cc1C=NNc1ccc(O)c(C(C)=O)c1</smiles>

Scheme 1: The Schiff bases synthesized in this study.

\section{EXPERIMENTAL SECTION}

\section{Chemistry}

${ }^{1} \mathrm{H}$ - and ${ }^{13} \mathrm{C}-\mathrm{NMR}$ spectra of the imine compounds were measured using AC Bruker $400 \mathrm{MHz}$ NMR spectrometer in d-methanol at ambient temperature. FT-IR spectra were recorded on a Jasco FT-IR 4700 spectrometer in the range of 400-4000 $\mathrm{cm}^{-1}$. Elemental analyses were recorded on a Elementar Vario Micro Cube elemental analyzer. Solvents and chemicals were used as received from commercial sources.

\section{Docking Studies}

Docking calculations were made by DockingServer (http://www.dockingserver.com). In order to energy minimization of ligand molecules, the MMFF94 force field was used by DockingServer (27). Gasteiger partial charges were added to the ligand atoms. Non-polar hydrogen atoms were combined, and rotatable bonds were defined. Docking calculations were made on AChE (PDB ID: 2ckm) and BChE (PDB ID: $1 \mathrm{pOi})$ proteins. The addition of essential hydrogen atoms, Kollman united atom type charges, and solvation parameters was carried out by AutoDock tools (28). Affinity (grid) maps of $100 \times 100 \times 100 \AA$ grid points and $0.375 \AA$ spacing were created by the aid of the Autogrid program (28). For the calculation of the van der Waals and the electrostatic terms, AutoDock parameter set- and distance- dependent dielectric functions were used. Docking simulations were made through the Lamarckian genetic algorithm (LGA) and the Solis \& Wets local search method (29). Initial position, orientation, and torsions of the ligand molecules were set randomly. Every docking experiment included 100 runs that were set to terminate after a maximum of 2500000 energy evaluations. The population size was adjusted to 150 . During the search, a translational step of $0.2 \AA$, and quaternion and torsion steps of 5 were used. 


\section{Experimental}

Fluoro- or chlorophenylhydrazine $(6 \mathrm{mmol})$ was placed in a round-bottom flask with ethanol (30 $\mathrm{mL}$ ). After addition of $\mathrm{NEt}_{3}$, this solution was mixed until all content was dissolved. Then, the carbonyl compound ( $6 \mathrm{mmol}$ ) was added to the clear solution. The reaction mixture was mixed for a couple of days. During this time the solution has changed to yellow or orange. After reaction's completion, reaction mixture was left to crystallization and the obtained precipitate was washed with ethanol and diethyl ether.

1a: Yield 55\%; mp: $161{ }^{\circ} \mathrm{C}$. FT-IR $\left(\mathrm{cm}^{-1}\right): 3320$ $(\mathrm{N}-\mathrm{H}), \quad 3268(\mathrm{O}-\mathrm{H}), \quad 2999 \quad(\mathrm{C}-\mathrm{H}), \quad 1596$ (azomethine, $\mathrm{C}=\mathrm{N}) ;{ }^{1} \mathrm{H}-\mathrm{NMR} \quad\left(\mathrm{CH}_{3} \mathrm{OH}-\mathrm{d}_{4}, \delta\right.$, ppm): $2.33\left(3 \mathrm{H}, \mathrm{s}, \mathrm{CH}_{3}\right), 6.34(1 \mathrm{H}, \mathrm{s}, \mathrm{CH}), 6.38$ $(1 \mathrm{H}, \mathrm{d}, \mathrm{CH}), 7.01(4 \mathrm{H}, \mathrm{dd}, \mathrm{CH}), 7.35(1 \mathrm{H}, \mathrm{d}, \mathrm{CH})$. ${ }^{13} \mathrm{C}-\mathrm{NMR}\left(\mathrm{CH}_{3} \mathrm{OH}-\mathrm{d}_{4}, \delta, \mathrm{ppm}\right): 11.29,102.74$, 106.43, 112.82, 113.51, 115.05, 115.28, 127.97, $142.22,149.30,155.95,158.30,158.85,159.34$. Anal. calcd. for $\mathrm{C}_{14} \mathrm{H}_{13} \mathrm{FN}_{2} \mathrm{O}_{2}(260.27 \mathrm{~g} / \mathrm{mol})$ : C, 64.61; $\mathrm{H}, 5.03 ; \mathrm{N}, 10.76$. Found: $\mathrm{C}, 64.47 ; \mathrm{H}$, $5.52 ; \mathrm{N}, 11.09 \%$.

1b: Yield 62\%; mp: $198{ }^{\circ} \mathrm{C}$ (decomp.). FT-IR $\left(\mathrm{cm}^{-1}\right)$ : $3056(\mathrm{O}-\mathrm{H}), 2954,2910(\mathrm{C}-\mathrm{H}), 1578$ (azomethine, $\mathrm{C}=\mathrm{N}) ;{ }^{1} \mathrm{H}-\mathrm{NMR} \quad\left(\mathrm{CH}_{3} \mathrm{OH}-\mathrm{d}_{4}, \delta\right.$, ppm): $2.81\left(3 \mathrm{H}, \mathrm{s}, \mathrm{CH}_{3}\right), 6.53(1 \mathrm{H}, \mathrm{d}, \mathrm{CH}), 6.60$ $(1 \mathrm{H}, \mathrm{dd}, \mathrm{CH}), 6.99(2 \mathrm{H}, \mathrm{dd}, \mathrm{CH}), 7.35(2 \mathrm{H}, \mathrm{dd}$, $\mathrm{CH}), 7.78(1 \mathrm{H}, \mathrm{d}, \mathrm{CH}) .{ }^{13} \mathrm{C}-\mathrm{NMR}\left(\mathrm{CH}_{3} \mathrm{OH}-\mathrm{d}_{4}, \delta\right.$, ppm): 15.06, 102.45, 107.86, 109.57, 114.96, $115.98,126.74,129.02,129.15,133.88,143.31$, 143.72, 161.42, 165.87. Anal. calcd. for $\mathrm{C}_{14} \mathrm{H}_{13} \mathrm{ClN}_{2} \mathrm{O}_{2}(276.72 \mathrm{~g} / \mathrm{mol}): \mathrm{C}, 60.77 ; \mathrm{H}, 4.74$; $\mathrm{N}, 10.12$. Found: C, $60.52 ; \mathrm{H}, 5.25 ; \mathrm{N}, 10.89 \%$.

2a: Yield 43\%; mp: $197{ }^{\circ} \mathrm{C}$ (decomp.). FT-IR $\left(\mathrm{cm}^{-1}\right): 3203(\mathrm{~N}-\mathrm{H}), \quad 3046(\mathrm{O}-\mathrm{H}), 1564$ (azomethine, $\mathrm{C}=\mathrm{N}) ;{ }^{1} \mathrm{H}-\mathrm{NMR} \quad\left(\mathrm{CH}_{3} \mathrm{OH}-\mathrm{d}_{4}, \delta\right.$, ppm): $6.76(1 \mathrm{H}, \mathrm{s}, \mathrm{CH}), 6.90(1 \mathrm{H}, \mathrm{d}, \mathrm{CH}), 7.05$ $(4 \mathrm{H}, \mathrm{dd}, \mathrm{CH}), 7.22(1 \mathrm{H}, \mathrm{dd}, \mathrm{CH}), 8.22(1 \mathrm{H}, \mathrm{s}, \mathrm{CH})$. ${ }^{13} \mathrm{C}-\mathrm{NMR}\left(\mathrm{CH}_{3} \mathrm{OH}-\mathrm{d}_{4}, \delta, \mathrm{ppm}\right): 113.61,115.14$, $115.25,115.40,115.48,123.10,123.42,141.29$, $146.05,150.70,159.14,159.88$. Anal. calcd. for $\mathrm{C}_{13} \mathrm{H}_{11} \mathrm{FN}_{2} \mathrm{O}_{2}(246.24 \mathrm{~g} / \mathrm{mol}): \mathrm{C}, 63.41 ; \mathrm{H}, 4.50$; $\mathrm{N}, 11.38$. Found: C, 63.79; H, 3.95; N, $11.87 \%$.

2b: Yield 85\%; mp: $194{ }^{\circ} \mathrm{C}$ (decomp.). FT-IR $\left(\mathrm{cm}^{-1}\right)$ : $3285(\mathrm{~N}-\mathrm{H}), \quad 3063(\mathrm{O}-\mathrm{H}), 1564$ (azomethine, $\mathrm{C}=\mathrm{N}) ;{ }^{1} \mathrm{H}-\mathrm{NMR} \quad\left(\mathrm{CH}_{3} \mathrm{OH}-\mathrm{d}_{4}, \delta\right.$, ppm): $6.89(1 \mathrm{H}, \mathrm{d}, \mathrm{CH}), 7.03(2 \mathrm{H}, \mathrm{dd}, \mathrm{CH}), 7.19$ $(1 \mathrm{H}, \mathrm{dd}, \mathrm{CH}), 7.25(2 \mathrm{H}, \mathrm{dd}, \mathrm{CH}), 7.38(1 \mathrm{H}, \mathrm{d}, \mathrm{CH})$,
$8.17(1 \mathrm{H}, \mathrm{s}, \mathrm{CH}) .{ }^{13} \mathrm{C}-\mathrm{NMR}\left(\mathrm{CH}_{3} \mathrm{OH}-\mathrm{d}_{4}, \delta, \mathrm{ppm}\right)$ : $113.33,114.35,115.33,116.01,122.85,123.88$, $124.68,128.74,129.02,144.02,145.93,149.02$, 150.08. Anal. calcd. for $\mathrm{C}_{13} \mathrm{H}_{11} \mathrm{ClN}_{2} \mathrm{O}_{2}$ (262.69 $\mathrm{g} / \mathrm{mol})$ : $\mathrm{C}, 59.44 ; \mathrm{H}, 4.22 ; \mathrm{N}, 10.66$. Found: $\mathrm{C}$, $59.08 ; \mathrm{H}, 5.02 ; \mathrm{N}, 11.41 \%$.

3a: Yield 61\%; mp: $176{ }^{\circ} \mathrm{C}$. FT-IR $\left(\mathrm{cm}^{-1}\right): 3305$ $(\mathrm{N}-\mathrm{H}), 3103,3083(\mathrm{C}-\mathrm{H}), 1575$ (azomethine, $\mathrm{C}=\mathrm{N}), 1339,1295\left(\mathrm{NO}_{2}\right) ;{ }^{1} \mathrm{H}-\mathrm{NMR}\left(\mathrm{CH}_{3} \mathrm{OH}-\mathrm{d}_{4}, \delta\right.$, ppm): $7.05(2 \mathrm{H}, \mathrm{dd}, \mathrm{CH}), 7.15(2 \mathrm{H}, \mathrm{dd}, \mathrm{CH}), 7.62$ $(1 \mathrm{H}, \mathrm{d}, \mathrm{CH}), 8.05(1 \mathrm{H}, \mathrm{dd} \mathrm{CH}), 8.15(1 \mathrm{H}, \mathrm{s}, \mathrm{CH})$, $8.82(1 \mathrm{H}, \mathrm{s}, \mathrm{CH}) .{ }^{13} \mathrm{C}-\mathrm{NMR}\left(\mathrm{CH}_{3} \mathrm{OH}-\mathrm{d}_{4}, \delta, \mathrm{ppm}\right)$ : 113.35, 115.13, 115.36, 119.92, 121.91, 129.52, 130.70, 135.09, 137.14, 141.06, 147.08. Anal. calcd. for $\mathrm{C}_{13} \mathrm{H}_{9} \mathrm{ClFN}_{3} \mathrm{O}_{2}(293.68 \mathrm{~g} / \mathrm{mol})$ : C, 53.17 ; $\mathrm{H}, 3.09 ; \mathrm{N}, 14.31$. Found: C, 52.83; H, 3.47; N, $14.81 \%$.

3b: Yield $72 \%$; mp: $188{ }^{\circ} \mathrm{C}$. FT-IR $\left(\mathrm{cm}^{-1}\right): 3301$ $(\mathrm{N}-\mathrm{H}), 3094,3074(\mathrm{C}-\mathrm{H}), 1575$ (azomethine, $\mathrm{C}=\mathrm{N}), 1340,1289\left(\mathrm{NO}_{2}\right) ;{ }^{1} \mathrm{H}-\mathrm{NMR}\left(\mathrm{CH}_{3} \mathrm{OH}-\mathrm{d}_{4}, \delta\right.$, ppm): $7.13(2 \mathrm{H}, \mathrm{dd}, \mathrm{CH}), 7.25(2 \mathrm{H}, \mathrm{dd}, \mathrm{CH}), 7.62$ $(1 \mathrm{H}, \mathrm{d}, \mathrm{CH}), 8.05(1 \mathrm{H}, \mathrm{dd}, \mathrm{CH}), 8.17(1 \mathrm{H}, \mathrm{s}, \mathrm{CH})$, $8.81(1 \mathrm{H}, \mathrm{d}, \mathrm{CH}) .{ }^{13} \mathrm{C}-\mathrm{NMR}\left(\mathrm{CH}_{3} \mathrm{OH}-\mathrm{d}_{4}, \delta, \mathrm{ppm}\right)$ : $113.59,120.02,122.17,124.54,128.76,130.45$, 130.75, 135.19, 137.33, 143.37, 147.03. Anal. calcd. for $\mathrm{C}_{13} \mathrm{H}_{9} \mathrm{Cl}_{2} \mathrm{~N}_{3} \mathrm{O}_{2}(310.13 \mathrm{~g} / \mathrm{mol}): \mathrm{C}, 50.35$; $\mathrm{H}, 2.93$; N, 13.55. Found: C, 50.57; H, 3.37; N, $13.98 \%$.

\section{RESULTS AND DISCUSSION}

The reaction of carbonyl compounds with fluoroor chloro-phenylhydrazines in an equimolar ratio completed in a couple of days and target compounds were obtained by crystallization from EtOAc:hexane solvent system (2:1) with moderate to high yields. The compounds were moisture- and air-stable, and soluble in methanol and DMSO. Their structures were proved by FTIR, ${ }^{1} \mathrm{H}$ - and ${ }^{13} \mathrm{C}-\mathrm{NMR}$ spectroscopic methods.

\section{FT-IR Spectra}

The important IR bands were presented in the experimental section. Besides, FT-IR spectra of 1a was shown in Figure 1 . The sharp $\mathrm{N}-\mathrm{H}$ band of hydrazine compound in 1a was observed at 3320 $\mathrm{cm}^{-1}$ as overlapped with broad $\mathrm{O}-\mathrm{H}$ stretching vibrations around $3268 \mathrm{~cm}^{-1}$. The band at 1596 $\mathrm{cm}^{-1}$ was indicator of the imine bond. Other Schiff bases were observed to exhibit FT-IR spectra with similar frequencies and no important changes. 


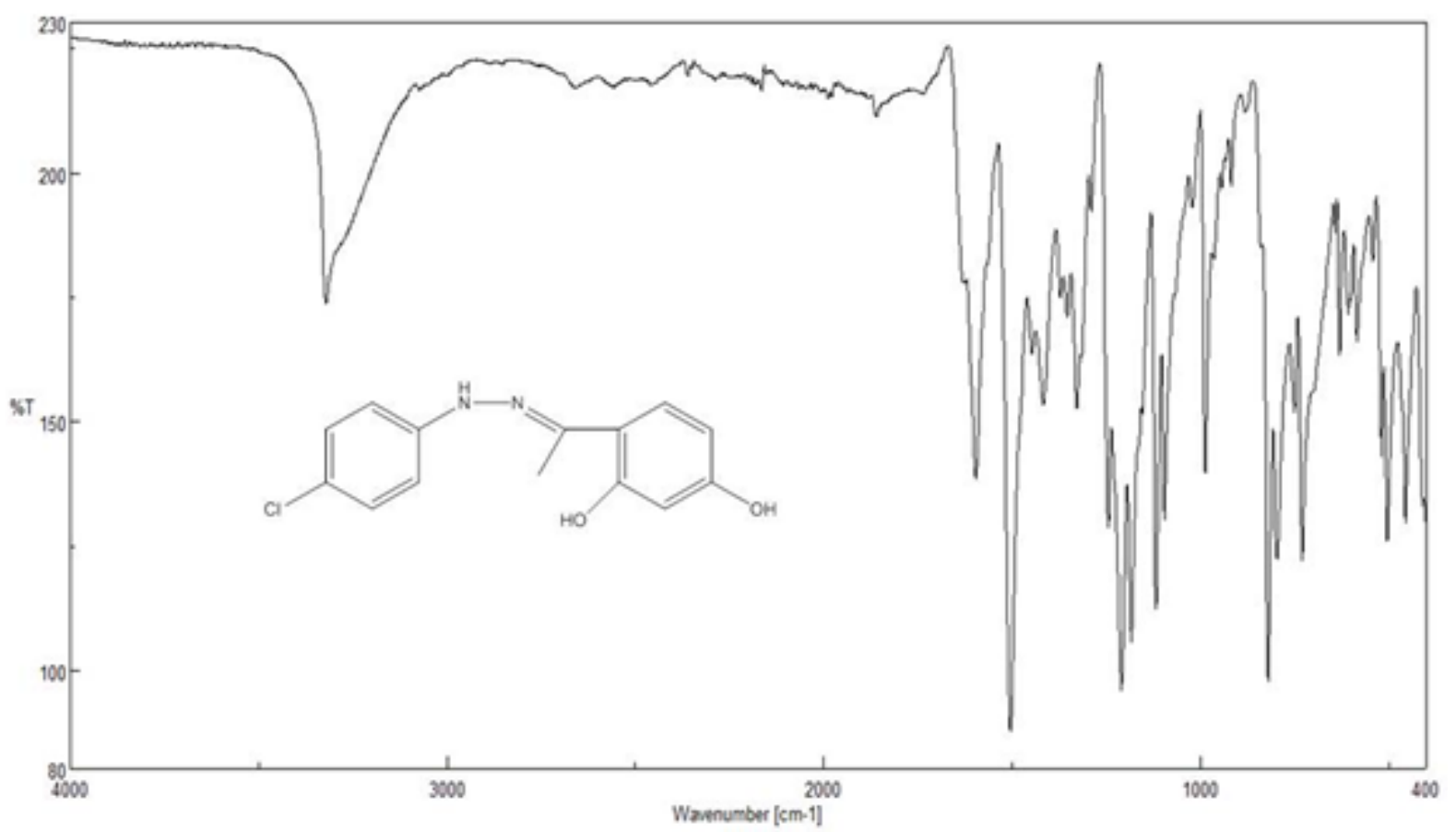

Figure 1: FT-IR spectrum of $\mathbf{1 a .}$

\section{NMR Spectra}

The ${ }^{1} \mathrm{H}$ - and ${ }^{13} \mathrm{C}-\mathrm{NMR}$ spectra of all compounds confirmed the expected Schiff base structures. The ${ }^{1} \mathrm{H}$ - and ${ }^{13} \mathrm{C}-\mathrm{NMR}$ spectra of $1 \mathrm{a}$ were shown in Figure 2. The singlet at about $2.33 \mathrm{ppm}$ was induced by the three protons of the methyl group. The other singlet was attributed to the methine proton placed between two tertiary aromatic carbon of carbonyl compound. While one of the two doublet peaks belonging to carbonyl compound segment was observed at $6.38 \mathrm{ppm}$, the other one originating from methine proton adjacent to imine group was at $7.35 \mathrm{ppm}$. As it comes to phenylhydrazine ring protons, they were observed as overlapped at $7.01 \mathrm{ppm} .{ }^{13} \mathrm{C}$ NMR peaks were in accordance with that of ${ }^{1} \mathrm{H}$ NMR peaks.
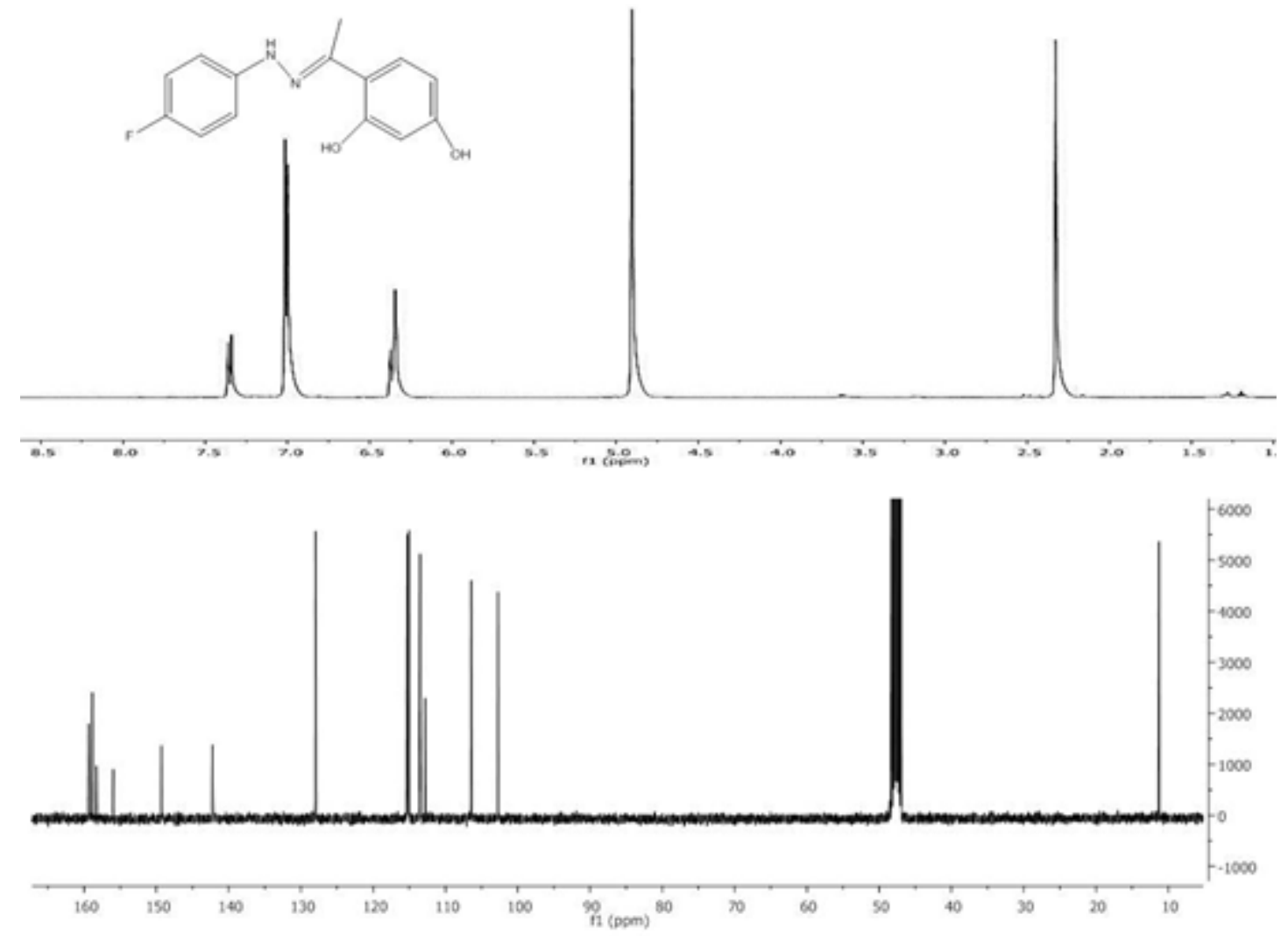

Figure 2: ${ }^{1} \mathrm{H}$ - and ${ }^{13} \mathrm{C}-\mathrm{NMR}$ spectra of $\mathbf{1 a}$. 


\section{Molecular Docking Studies}

Schiff bases were docked against AChE (PDB ID: 2CKM) and BChE (PDB ID: 1POI) downloaded from Protein Data Bank by using Molecular Docking Server (Figure 3). Their binding affinity

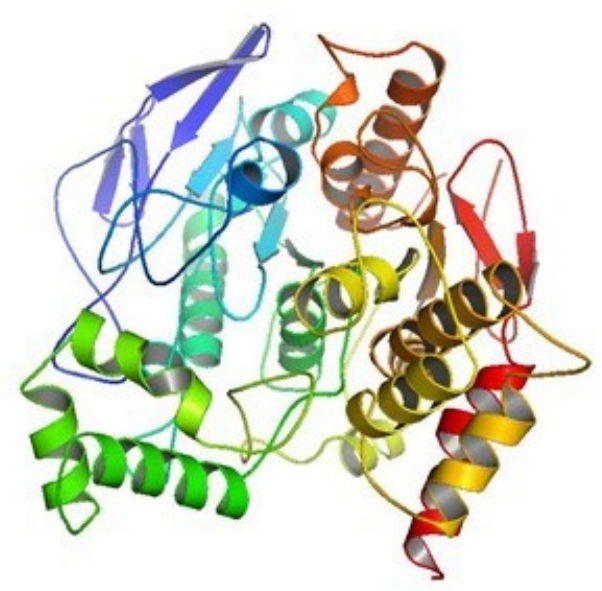

Acetylcholinesterase (2CKM) and interaction of amino acid residues near their binding sites were also examined. Besides, pymol visual images of interacted proteins and ligands were shown in Table 1.

Figure 3: PDB structure of the proteins.

The amino acid fragments predicted to form hydrogen bonds with ligands were GLU 374, GLU 455, TYR 282, TYR 121, ASN 230, SER 87, SER 235, GLN 514, ARG 515, ALA 516, VAL 453. Among six ligands, fluoro derivative had the higher activity against butyrylcholinesterase while chloro derivative exhibited the higher binding affinity against acetylcholinesterase (Table 2).

Table 1: Pymol visual images of ligand docked proteins.

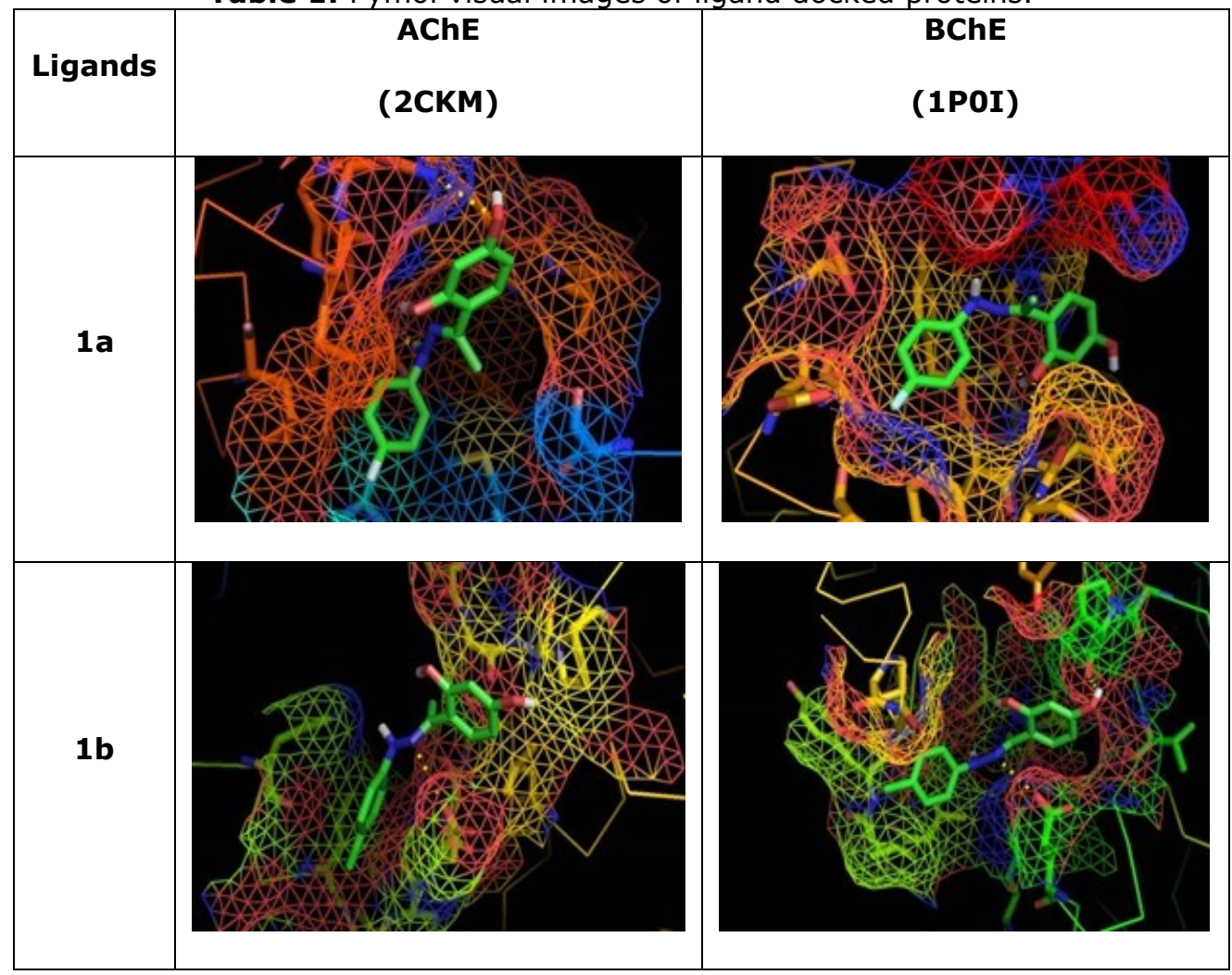




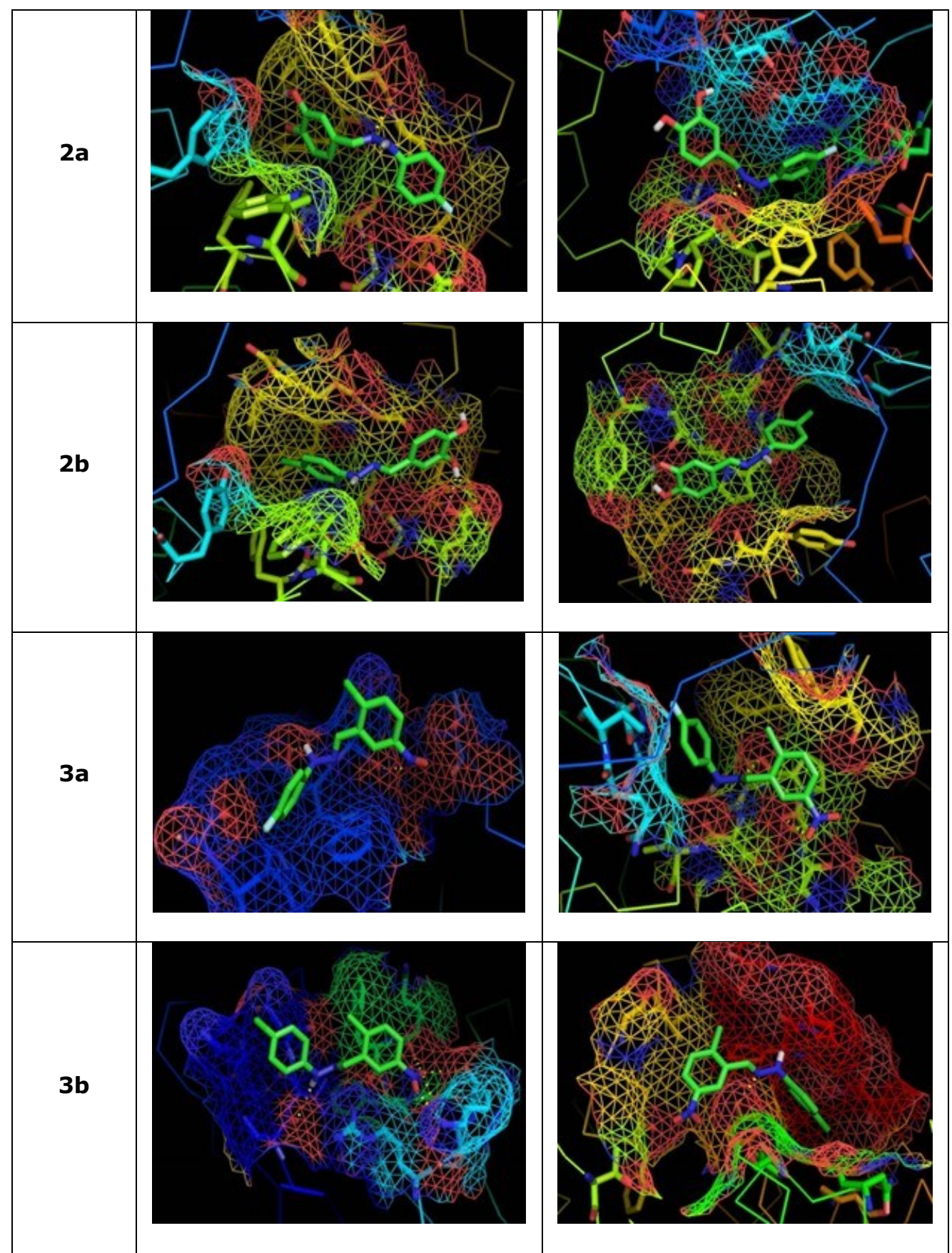

Table 2: Calculated binding affinity values between proteins and ligands.

\begin{tabular}{ccccc}
\hline & \multicolumn{2}{c}{ 2CKM } & \multicolumn{2}{c}{ 1POI } \\
\cline { 2 - 5 } Ligand & $\begin{array}{c}\text { Docking Score } \\
\text { (kcal/mol) }\end{array}$ & $\begin{array}{c}\text { Estimated } \\
\text { Inhibition } \\
\text { Constant }\end{array}$ & $\begin{array}{c}\text { Docking Score } \\
\text { (kcal/mol) }\end{array}$ & $\begin{array}{c}\text { Estimated } \\
\text { Inhibition } \\
\text { Constant }\end{array}$ \\
\hline 1a & -2.62 & $12 \mathrm{mM}$ & -3.14 & $5 \mathrm{mM}$ \\
$\mathbf{1 b}$ & -2.76 & $9.42 \mathrm{mM}$ & -3.85 & $1.52 \mathrm{mM}$ \\
2a & -3.23 & $4.31 \mathrm{mM}$ & -3.39 & $3.25 \mathrm{mM}$ \\
$\mathbf{2 b}$ & -3.61 & $2.26 \mathrm{mM}$ & -3.28 & $3.96 \mathrm{mM}$ \\
3a & -3.54 & $2.53 \mathrm{mM}$ & -4.14 & $926.18 \mu \mathrm{M}$ \\
3b & -4.31 & $692.01 \mu \mathrm{M}$ & -3.60 & $2.28 \mathrm{mM}$ \\
\hline
\end{tabular}


Tacrine (THA) is the first cholinesterase inhibitor, approved by the FDA and then withdrawn from the market because of its adverse effects. Showing lower side effects in comparison with THA, 7-methoxy derivative (7-MEOTA) was observed to exhibit similar activity against cholinesterases. The Schiff base compounds 1a3b synthesized in this study exhibited lower docking scores in comparison with THA [-9.9 $\mathrm{kcal} / \mathrm{mol}$ for AChE $(2 \mathrm{ckm})$ and $-9.5 \mathrm{kcal} / \mathrm{mol}$ for BChE (1p0i)] and 7-MEOTA [-9.8 kcal/mol for AChE (2ckm) and $-9.3 \mathrm{kcal} / \mathrm{mol}$ for BChE (1p0i)] (30).

\section{CONCLUSIONS}

In conclusion, the Schiff bases composed of phenylhydrazine halogen derivatives and carbonyl compounds were synthesized and characterized by spectroscopic methods (FT-IR, ${ }^{1} \mathrm{H}$ - and ${ }^{13} \mathrm{C}$-NMR). The compounds were prepared by mixing fluoro- or chloro-phenylhydrazine with the carbonyl compounds in equimolar amount in ethanol. The results of spectroscopic methods were used to explain the structures of the compounds and verified the predicted Schiff base structures. Besides, the compounds which were likely to exhibit inhibition activity on Alzheimer's disease were examined by molecular docking methods. The possibility of exhibiting inhibition activity of the Schiff bases on Alzheimer's disease was estimated based on similar chemical groups (phenyl ring and nitrogen atoms) included in their structure with Tacrine. All of the compounds exhibited low to mild binding affinities against acetylcholinesterase and butyrylcholinesterase in comparison with reference compounds (THA and 7-MEOTA). Schiff bases $\mathbf{3 a}$ and $\mathbf{3 b}$ derived from 2-chloro-5-nitrobenzaldehyde showed best results for both cholinesterase proteins. According to the calculated results, especially $\mathbf{3 a}$ and $\mathbf{3} \mathbf{b}$ were decided to be modified so as to use potential therapeutic agents for treating Alzheimer's disease.

\section{REFERENCES}

1. Kumar R, Mani G. Exhibition of the Brønsted acid-base character of a Schiff base in palladium(II) complex formation: lithium complexation, fluxional properties and catalysis of Suzuki reactions in water. Dalt Trans. 2015;44(15):6896-908.

2. Nejati K, Rezvani Z, Massoumi B. Syntheses and investigation of thermal properties of copper complexes with azo-containing Schiffbase dyes. Dye Pigment. 2007;75(3):653-7.

3. Ebenso EE, Isabirye DA, Eddy NO. Adsorption and Quantum Chemical Studies on the Inhibition Potentials of Some Thiosemicarbazides for the Corrosion of Mild Steel in Acidic Medium. Int J Mol Sci [Internet]. 2010;11(6):2473-98.
4. Cinarli A, Gürbüz D, Tavman A, Birteksöz AS. Synthesis, spectral characterizations and antimicrobial activity of some Schiff bases of 4chloro-2-aminophenol. Bull Chem Soc Ethiop. $2011 ; 25(3): 407-17$.

5. Alshaheri AA, Tahir MIM, Rahman MBA, Begum T, Saleh TA. Synthesis, characterisation and catalytic activity of dithiocarbazate Schiff base complexes in oxidation of cyclohexane. J Mol Liq. $2017 ; 240: 486-96$.

6. Cuesta-Aluja L, Campos-Carrasco A, Castilla J, Reguero M, Masdeu-Bultó AM, Aghmiz A. Highly active and selective $\mathrm{Zn}$ (II)-NN'O Schiff base catalysts for the cycloaddition of CO2to epoxides. J CO2 Util [Internet]. 2016;14:10-22.

7. Silku P, Özkinali S, Öztürk Z, Asan A, Köse DA. Synthesis of novel Schiff Bases containing acryloyl moiety and the investigation of spectroscopic and electrochemical properties. J Mol Struct. 2016;1116:72-83.

8. Karaer H, Gümrükçüoğlu IE. Synthesis and spectral characterisation of novel azoazomethine dyes. Turkish J Chem. $1999 ; 23(1): 67-71$.

9. Kajal A, Bala S, Kamboj S, Sharma N, Saini V. Schiff Bases: A Versatile Pharmacophore. J Catal. 2013;2013:1-14.

10. Dayakar C, Jyothi D, Suman P, Raju BC. Condensation of Ortho-phenylenediamines and Phenylhydrazines with Ethyl 4-Chloro-3oxobutanoate: A Facile Approach for the Synthesis of Substituted 1 H-Benzimidazoles, Pyrazolones, and Pyrazoles. Synth Commun [Internet]. 2015;45(14):1642-51.

11. Anush SM, Vishalakshi B, Kalluraya B, Manju N. Synthesis of pyrazole-based Schiff bases of Chitosan: Evaluation of antimicrobial activity. Int $\mathrm{J}$ Biol Macromol [Internet]. 2018;119:446-52.

12. Lv XH, Ren ZL, Li DD, Ruan BF, Li QS, Chu $M J$, et al. Discovery of novel double pyrazole Schiff base derivatives as anti-tobacco mosaic virus (TMV) agents. Chinese Chem Lett [Internet]. 2017;28(2):377-82.

13. Wazalwar SS, Banpurkar AR, Perdih F. Synthesis, Characterization, Molecular Docking Studies and Anticancer Activity of Schiff Bases Derived from 3-(Substituted phenyl)-1-phenyl$1 \mathrm{H}$-pyrazole-4-carbaldehyde and 2-Aminophenol. ] Chem Crystallogr [Internet]. 2018;48(4):18599.

14. del Mar Conejo M, Cantero J, Pastor A, Álvarez E, Galindo A. Synthesis, structure and properties of nickel and copper complexes containing $\mathrm{N}, \mathrm{O}$-hydrazone Schiff base ligand. Inorganica Chim Acta. 2018;470:113-8. 
15. Lapasam A, Dkhar L, Joshi N, Poluri KM, Kollipara MR. Antimicrobial selectivity of ruthenium, rhodium, and iridium half sandwich complexes containing phenyl hydrazone Schiff base ligands towards $B$. thuringiensis and $P$. aeruginosa bacteria. Inorganica Chim Acta [Internet]. 2019;484(August 2018):255-63.

16. Abedinifar $F$, Farnia SMF, Mahdavi $M$, Nadri H, Moradi A, Ghasemi JB, et al. Synthesis and cholinesterase inhibitory activity of new 2benzofuran carboxamide-benzylpyridinum salts. Bioorg Chem. 2018;80:180-8.

17. Abbas-Mohammadi $M$, Moridi Farimani $M$, Salehi P, Nejad Ebrahimi S, Sonboli A, Kelso C, et al. Acetylcholinesterase-inhibitory activity of Iranian plants: Combined HPLC/bioassay-guided fractionation, molecular networking and docking strategies for the dereplication of active compounds. J Pharm Biomed Anal. 2018;158:471-9.

18. Makhaeva GF, Boltneva NP, Lushchekina S V., Rudakova E V., Serebryakova OG, Kulikova LN, et al. Synthesis, molecular docking, and biological activity of 2-vinyl chromones: Toward selective butyrylcholinesterase inhibitors for potential Alzheimer's disease therapeutics. Bioorganic Med Chem. 2018;26(16):4716-25.

19. Andrade-Jorge $E$, Sánchez-Labastida LA, Soriano-Ursúa MA, Guevara-Salazar JA, TrujilloFerrara JG. Isoindolines/isoindoline-1,3-diones as AChE inhibitors against Alzheimer's disease, evaluated by an improved ultra-micro assay. Med Chem Res. 2018;27(9):2187-98.

20. Larik FA, Shah MS, Saeed A, Shah HS, Channar PA, Bolte $M$, et al. New cholinesterase inhibitors for Alzheimer's disease: Structure activity relationship, kinetics and molecular docking studies of 1-butanoyl-3-arylthiourea derivatives. Int J Biol Macromol. 2018;116:14450.

21. Arumugam $N$, Almansour AI, Suresh Kumar R, Altaf M, Padmanaban R, Sureshbabu P, et al. Spiropyrrolidine/spiroindolizino[6,7b]indole heterocyclic hybrids: Stereoselective synthesis, cholinesterase inhibitory activity and their molecular docking study. Bioorg Chem. 2018;79:64-71.

22. Kilic B, Gulcan HO, Aksakal F, Ercetin T, Oruklu N, Umit Bagriacik $E$, et al. Design and synthesis of some new carboxamide and propanamide derivatives bearing phenylpyridazine as a core ring and the investigation of their inhibitory potential on invitro acetylcholinesterase and butyrylcholinesterase. Bioorg Chem. $2018 ; 79: 235-49$.

23. Senthil SL, Chandrasekaran R, Arjun HA, Anantharaman $P$. In vitro and in silico inhibition properties of fucoidan against a-amylase and aD-glucosidase with relevance to type 2 diabetes mellitus. Carbohydr Polym. 2019;209:350-5.

24. Ghaleb A, Aouidate A, Bouachrine $M$, Lakhlifi T, Sbai A. Discovery of Novel 1,2,3Triazole Analogues as Anti-Tuberculosis agents Using 3D QSAR, Molecular Docking, and In Silico ADMET Screening. Anal Bioanal Chem Res. 2019;6(1):215-29.

25. Almutairi MS, Leenaraj DR, Ghabbour HA, Joe IH, Attia MI. Spectroscopic identification, structural features, Hirshfeld surface analysis and molecular docking studies on stiripentol: An orphan antiepileptic drug. J Mol Struct. 2019;1180:110-8.

26. Chen Y, Liu J, Geng S, Liu Y, Ma H, Zheng J, et al. Lipase-catalyzed synthesis mechanism of tri-acetylated phloridzin and its antiproliferative activity against HepG2 cancer cells. Food Chem. 2019;277:186-94.

27. Halgren TA. Merck molecular force field. I. Basis, form, scope, parameterization, and performance of MMFF94. J Comput Chem. $1996 ; 17(5-6): 490-519$.

28. Morris GM, Goodsell DS, Halliday RS, Huey R, Hart WE, Belew RK, et al. Automated docking using a Lamarckian genetic algorithm and an empirical binding free energy function. J Comput Chem. 1998;19(14):1639-62.

29. Solis FJ, Wets RJ-B. Minimization by Random Search Techniques. Math Oper Res. $1981 ; 6(1): 19-30$.

30. Spilovska K, Korabecny J, Kral J, Horova A, Musilek K, Soukup O, et al. 7-methoxytacrineadamantylamine heterodimers as cholinesterase inhibitors in Alzheimer's disease treatment Synthesis, biological evaluation and molecular modeling studies. Molecules. 2013;18(2):2397418. 